\title{
Predictors of Early Virological Response of Viral Hepatitis C to Combination Therapy with Pegylated Interferon Plus Ribavirin
}

\author{
Ahmed Faisal $^{1, *}$, Ashraf Anas Zytoon ${ }^{2}$, Abdel-Naser Gad Allah ${ }^{3}$, Alaa Dawood ${ }^{3}$ \\ ${ }^{1}$ Infectious and Endemic Diseases Unit, Internal Medicine Department, Suez Canal University, Egypt \\ ${ }^{2}$ Radiology Department, Faculty of Medicine, Menoufiya University, Egypt \\ ${ }^{3}$ Internal Medicine Department, Menoufiya University, Egypt \\ *Corresponding author: ahmedf65@yahoo.com
}

Received August 24, 2013; Revised September 09, 2013; Accepted September 15, 2013

\begin{abstract}
A combination therapy with pegylated interferon (PEG-IFN) plus ribavirin (RBV) has made it possible to achieve a sustained virological response (SVR) of $50 \%$ in refractory cases with genotype $1 \mathrm{~b}$ and high levels of plasma HCVRNA. Several factors including virus mutation and host factors such as age, gender, fibrosis of the liver, lipid metabolism, innate immunity, and single nucleotide polymorphism (SNPs) are reported to be correlated to therapeutic effects. However, it is difficult to determine which factor is the most important predictor for an individual patient. Data mining analysis is useful for combining all these together to predict the therapeutic effects, It is important to analyze blood tests and to predict therapeutic effects prior to initiating treatment. Our aim is to determine the independent contribution of factors including age, gender, viral load, liver fibrosis, hepatitis activity index sore, and the homeostasis model assessment of insulin resistance (HOMA-IR) score in predicting response to therapy in chronic hepatitis C (CHC). Multivariate analysis of factors predicting rapid (RVR) and sustained (SVR) virological response in 280 consecutive, treatment-naive $\mathrm{CHC}$ patients treated with peginterferon alpha and ribavirin in a prospective multicentre study.
\end{abstract}

Keywords: predictors of early virological, viral hepatitis $C$, combination therapy, pegylated interferon

Cite This Article: Ahmed Faisal, Ashraf Anas Zytoon, Abdel-Naser Gad Allah, and Alaa Dawood, "Predictors of Early Virological Response of Viral Hepatitis C to Combination Therapy with Pegylated Interferon Plus Ribavirin.” American Journal of Clinical Medicine Research 1, no. 4 (2013): 54-60. doi: 10.12691/ajcmr-14-3.

\section{Introduction}

Hepatitis $\mathrm{C}$ virus (HCV) is one of the most important Flaviviridae infections in humans and is the second most common cause of viral hepatitis [1]. The World Health Organization (WHO) estimates that about 3\% of the world's population has been infected with HCV and that there are more than 170 million chronic carriers who are at risk of developing liver cirrhosis and/or liver cancer [2]. Egypt contains the highest prevalence of hepatitis $\mathrm{C}$ in the world and a high morbidity and mortality from chronic liver disease, cirrhosis, and hepatocellular carcinoma. Approximately $12 \%$ of blood donors are seropositive for HCV antibodies [3]. A community-based study reported positive HCV RNA in sera of $9.8 \%$ of 1,126 representative Egyptian citizens [4].

Chronic HCV infection frequently results in liver cirrhosis and is associated with an elevated risk of developing hepatocellular carcinoma [5]. Although symptoms may be mild for decades, $20 \%$ of persistently infected individuals may eventually develop serious liver disease including cirrhosis and liver cancer [2]. The only effective treatment is based on interferon alpha (IFN- $\alpha$ ). Treatment with either IFN- $\alpha$ alone or in combination with ribavirin leads to a sustained virological response (SVR) in $20 \%$ to $56 \%$ of patients with chronic hepatitis C [6,7]. The combination of interferon and ribavirin is the preferred treatment and achieves a better response than interferon or ribavirin alone [8]. the more rapidly $\mathrm{HCV}$ RNA becomes negative during treatment, the higher the rate of SVR [9].

However, nonresponse to this therapy remains common and is associated with several factors such as $\mathrm{HCV}$ genotype, duration of a person's HCV infection and HCV viral load in addition to host factors such as sex, HLA type and cytokine polymorphisms [10,11]. Patient age, grade of liver inflammation and ethnicity have also been shown to influence response to therapy $[12,13]$. The strongest predictors for a SVR to treatment is the $\mathrm{HCV}$ genotype, with $\mathrm{HCV}$ genotype $1(\mathrm{HCV}-1)$ being the least sensitive to IFN- $\alpha$ based therapy $[14,15]$.

Several studies are available on the response rates to combinatorial IFN- $\alpha$ /ribavirin treatment of hepatitis $\mathrm{C}$ in Pakistan [16,17], however, these do not describe positive and negative predictors for the SVR rates. The aim of this study was to determine the efficacy and safety of a 24 
weeks or 48 weeks treatment with IFN- $\alpha$ plus ribavirin in patients with chronic hepatitis $C$ genotypes none- 1 and 1 respectively and to identify factors that impaired response to antiviral therapy. We focused our study on naïve patients that had not previously received antiviral treatment and who presented with HCV genotypes non-1 and 1. Several baseline and on-treatment variables affect the likelihood of achieving SVR [18]. Older age, advanced stage of fibrosis, African-American ethnicity and HCVrelated factors, including HCV genotype 1 and high viral load at baseline, predict poor response to anti-viral therapy. Furthermore, metabolic factors, such as high body mass index (BMI), presence and severity of liver steatosis and increasing homeostasis model assessment of insulin resistance (HOMA-IR) score have been reported as negative predictors of response $[19,20]$. On the other hand, early on-treatment kinetics of HCV RNA, e.g. undetectable HCV RNA at week 4, has a high positive predictive value of SVR $[21,22]$.

\section{Patients and Subjects}

\subsection{Patients Demographics}

This study included fifty five consecutive chronic hepatitis $\mathrm{C}$ (CHC) patients. Their age ranged from 18-60 years eligible for combined therapy of of Pegylated interferon (PEG-IFN) and Ribavirin. All patients undergone a percutaneous liver biopsy at the beginning of treatment in the Gastroenterology and Hepatology Unit of Suez Canal University Hospital and Al Menoufyia university hospital between November 2010 and January 2012. All patients were subjected to

1. clinical evaluation; including demographic data, present history of smoking, alcohol consumption, presence of chronic diseases (DM, hypertension...), and past history of dental intervention, surgery or blood transfusion.

2. laboratory investigations; including, ALT, AST, Hemoglobin (Hb), Albumin, Bilirubin (Total and Direct), Alpha fetoprotein (AFP), Prothrombin time (PT), Antischistosomal antibody test.

3. Quantitative HCV RNA. After 12 weeks of treatment with combined PEG-IFN/Ribavirin therapy, to detect the early virologic response (EVR) was done. EVR is considered if the HCV RNA level is undetectable or if a greater than 2-log-fold reduction in HCV RNA level is present.

So, patients were divided into 2 groups:

1) Responders: those are patients whose PCR results showed EVR.

2) Non- responders: those are patients whose PCR results didn't show EVR.

The viral load result of respective patient was collected from patients. Samples were enrolled in the study after getting informed consent from each patient.

\subsection{Methods}

The serological and biochemical tests were done at Clinical Pathology department of Suez Canal University Hospital. Data were obtained from the patients' sheets. Quantitative HCV RNA was done using Real Time PCR technique in an API PRISM® 7000 thermocycler (applied biosystems, Foster city, CA) at the Oncology Diagnostic Unit of Suez canal University Hospital, by the unit's staff

Liver histology: For all patients, conventional liver histology was performed on formalin-fixed liver biopsy by pathologists at pathology department of Suez Canal University Hospital and Al Menoufyia university hospital. The liver fibrosis was staged on a 0-6 scale as follows: F0 = no fibrosis; F1 = Fibrous expansion of some portal areas; F2 = Fibrous expansion of most portal areas; F3 = Fibrous expansion of most portal areas with occasional portal to portal bridging; F4 = Fibrous expansion of most portal areas with marked bridging; F5 = Marked bridging with occasional nodules (incomplete cirrhosis); F6= Cirrhosis. The fibrosis stage can be classified to low stage fibrosis (stage 0-3), and high stage fibrosis (stage 4-6).The pathology report of all study subjects were obtained from the department. The histological activity index (HAI) can be classified as minimal (grade 0-3), mild (grade 4-8), moderate (grade 9-12) and severe (grade 13-18).

Estimation of IL-6 level plasma level was done by using IMMULITE $₫ 1000$ IL-6 (Siemens, Immulite, cat no. 06604071). Assessing insulin resistance:Insulin resistance was done by using the Homeostatic Model Assessment (HOMA). It is the product of the fasting values of glucose (G0) (expressed as mmol/L) and insulin (I0) (expressed as $\mu \mathrm{U} / \mathrm{mL}$ ) divided by a constant: 10XG0/22.5. Patients with HOMA-IR values $>2$ were considered insulin-resistant. Pasma samples were tested for insulin hormone level using AccuBindTM ELISA Microwells (Cat\# 2425-300, MonobindInc, Lake Forest, USA).

Detection of IL-6 -174 G > C (rs1800795) polymorphism: Genomic DNA was extracted from patients' and controls' peripheral blood leucocytes of EDTA anticoagulated blood using AxyPrep Blood Genomic DNA Miniprep Kit (Axygen Biosciences, USA). The integrity of the extracted DNA was assessed by performing DNA gel electrophoresis at 1\% concentration of agarose in $1 \mathrm{x}$ Tris Acetate EDTA (TAE) running buffer. The 1000 Spectrophotometer (NanoDrop Technologies Inc., Washington, USA). Genomic DNA samples extracted from blood samples extracted DNA samples were subjected to DNA quantitation using the NanoDrop ${ }^{\circledR}$ (ND)- were amplified by PCR technique with IL-6 gene promoter specific primers [19].

\section{Results}

As shown in Table 1, 77\% of patients responded to combined PEG INF and Ribaverin therapy while 23\% of patients didn't respond, the response rate was nearly similar in male patients (76\%) and female patients (78\%). The difference was statistically not significant. As shown in Table 2, there is significantly higher viral load in nonresponders than responders $(\mathrm{P}$ value $=0.04)$. The antischistosomal antibody was positive in high percentage of non-responders (64\%), but this was statistically not significant. Most patients have mild degree histological activity (79\% of total patients). The minimal HAI reported $100 \%$ response rate. The mild HAI reported $76 \%$ response rate. The moderate grade of HAI reported the lowest response rate of $50 \%$. There were no cases with severe grade of HAI. The difference between responders and non-responders was statistically not significant. The 
difference in other laboratory and pathological data (mean bilirubin, mean albumin, $\alpha$ fetoprotein, ALT and AST) was statistically not significant.

Table 3 shows that the CC genotype reported the higher response rate (80\%) than CG genotype (50\%) and GG genotype (57\%). There is no statistically significant difference in response to treatment between all genotypes of IL-6 -174 polymorphism, IL-6 level was significantly higher in the responders patients than non-responders patients $(\mathrm{P}$ value $=0.01)$, the mean stage of fibrosis was significantly higher in non-responders than in responders ( $\mathrm{P}$ value $=0.03$ ). Patients with low stage fibrosis (stage 0 $3)$ tend to have higher response rate (80\%) than patients with high stage fibrosis (stage 4-6) (response rate 50\%). This difference was statistically notsignificant,the mean fasting insulin level was higher in non-responders than in responders. But this difference was statistically not significant, there is no statistically significant difference in insulin resistance (HOMA-IR) between responders and non-responders.

Table 3 shows that IL-6 level was significantly higher in the responders patients than non-responders patients $(P$ value $=0.01$ ).the mean stage of fibrosis was significantly higher in non-responders than in responders $(\mathrm{P}$ value $=$ 0.03). Patients with low stage fibrosis (stage $0-3$ ) tend to have higher response rate $(80 \%)$ than patients with high stage fibrosis (stage 4-6) (response rate 50\%). This difference was statistically not significant. The mean fasting insulin level was higher in non-responders than in responders. But this difference was statistically not significant. There is no statistically significant difference in insulin resistance (HOMA-IR) between responders and non-responders.

In receiving operating characteristic curve (Figure 1), IL- 6 level $>2.15 \mathrm{pg} / \mathrm{ml}$ is significantly associated with EVR (p-value $=0.04$ ) with $81.1 \%$ sensitivity and $72.7 \%$ specificity (95\% CI: 0.521-0.889). The fibrosis stage at a cut off $>2 / 6$ is not associated with EVR with $32.4 \%$ sensitivity and $45.5 \%$ specificity (95\% CI: $0.153-0.488)$, this was near to statistical significance $(\mathrm{P}$ value $=0.07)$. The viral load (measured by PCR) at a cut off $>336,500$ $\mathrm{Iu} / \mathrm{ml}$ is also not associated with EVR with $56.8 \%$ sensitivity and $45.5 \%$ specificity (95\% CI: $0.389-0.754$ ) but this was statistically not significant.

Table 4 shows that by multivarient logistic regression analysis, IL-6 level is significantly an independent predictor of EVR (P value $=0.03$, OR: 1.865 , with $95 \%$ CI: 1.048-3.318) while the fibrosis stage is near to be significant predictor of EVR $(\mathrm{P}$ value $=0.08$, OR: 0.514 , with 95\% CI: 0.245-1.08.

\begin{tabular}{|c|c|c|c|}
\hline Table 1. Distribution of patients according to response to therapy \\
\hline & $\begin{array}{c}\text { Responders } \\
\text { N (\%) }\end{array}$ & $\begin{array}{c}\text { Non-responders } \\
\text { N (\%) }\end{array}$ & \\
\hline Patients (n=48) & $37(77 \%)$ & $11(23 \%)$ & \\
\hline Gender & & & p-value \\
Male & $26 / 34(76 \%)$ & $8 / 34(24 \%)$ & NS \\
female & $11 / 14(78 \%$ & $3 / 14(22 \%)$ & \\
\hline
\end{tabular}

Table 2. some demographic and laboratory data among responder and non-responder patients

\begin{tabular}{|c|c|c|c|}
\hline $\begin{array}{l}\text { Laboratory data } \\
\text { Mean } \pm \text { SD }\end{array}$ & $\begin{array}{c}\text { Responders } \\
(\mathrm{n}=37)\end{array}$ & $\begin{array}{c}\text { Non-responders } \\
(\mathrm{n}=11)\end{array}$ & $\mathrm{P}$ value \\
\hline$\alpha$-fetoprotein (ng/ml) & $2.3 \pm 1.3$ & $3.2 \pm 1.2$ & NS \\
\hline Viral load (PCR) & $450,701 \pm 426,559$ & $1498,406 \pm 3522,681$ & 0.04 \\
\hline AST (IU/L) & $36.0 \pm 28.0$ & $34.0 \pm 12.0$ & NS \\
\hline ALT (IU/L) & $36.0 \pm 23.0$ & $35.0 \pm 18.0$ & NS \\
\hline Albumin (gm/dl) & $4.0 \pm 0.43$ & $4.0 \pm 0.41$ & NS \\
\hline Bilirubin (mg/dl) & $0.74 \pm 0.25$ & $0.65 \pm 0.22$ & NS \\
\hline Histological activity index (HAI) & $6.1 \pm 1.9$ & $5.5 \pm 1.8$ & \\
\hline Minimal $(0-3)(n=5)$ & $5(100 \%)$ & $0(0 \%)$ & \\
\hline Mild (4-8) (n=38) & $29(76 \%)$ & $9(24 \%)$ & \\
\hline Moderate $(9-12)(n=4)$ & $2(50 \%)$ & $2(50 \%)$ & NS \\
\hline Severe $(13-18)(n=0)$ & $0(0 \%)$ & $0(0 \%)$ & \\
\hline \multicolumn{4}{|l|}{ anti-schistosomal antibody } \\
\hline Positive n (\%) & $21(55 \%)$ & $7(64 \%)$ & NS \\
\hline Negative n (\%) & $17(45 \%)$ & $4(36 \%)$ & \\
\hline
\end{tabular}

*Statistically significant difference (p-value $<0.05)$

Table 3. relation between the IL-6 -174 promoter polymorphism,IL-6,Fibrosis stage, fasting IL, and homa -IR and the response to treatment

\begin{tabular}{|c|c|c|c|}
\hline \multirow{4}{*}{$\begin{array}{c}\text { IL-6-174 polymorphism } \\
\text { CC }(\mathrm{n}=26) \mathrm{N}(\%) \\
\text { CG }(\mathrm{n}=6) \mathrm{N}(\%) \\
\text { GG }(\mathrm{n}=7) \mathrm{N}(\%)\end{array}$} & Responders $(n=37)$ & Non-responders $(\mathrm{n}=11)$ & P-value \\
\hline & $21(80 \%)$ & $5(20 \%)$ & \multirow{3}{*}{ NS } \\
\hline & $3(50 \%)$ & $3(50 \%)$ & \\
\hline & $4(57 \%)$ & $3(43 \%)$ & \\
\hline & Responders (n-37) & Non-responders(n=11) & \\
\hline IL-6 level (pg/ml) & $3.8 \pm 2.5$ & $2.0 \pm 1.7$ & $0.01^{*}$ \\
\hline Stage of fibrosis & & & \\
\hline Mean \pm SD & $2.1 \pm 1.1$ & $2.8 \pm 1.0$ & $0.03 *$ \\
\hline Low stage fibrosis (stage $0-3)(n=44)$ & $35 / 44(80 \%)$ & 9/44 (20\%) & NS \\
\hline High stage fibrosis (stage $4-6)(n=4)$ & $2 / 4(50 \%)$ & $2 / 4(50 \%)$ & NS \\
\hline Fasting insulin level $(\mu \mathrm{U} / \mathrm{ml}) \mathrm{M} / \mathrm{SD}$ & $10.8 \pm 9.4$ & $13 \pm 12.9$ & NS \\
\hline HOMA-IR M/SD & $4.0 \pm 3.6$ & $3.6 \pm 3.1$ & NS \\
\hline
\end{tabular}

*Statistically significant difference (p-value $<0.05$ )

Multivarient logistic regression for independent predictors of the response to antiviral therapy in chronic

hepatitis C patients treated with peg-interferon plus Ribavirin. (Method: by backward stepwise method) 


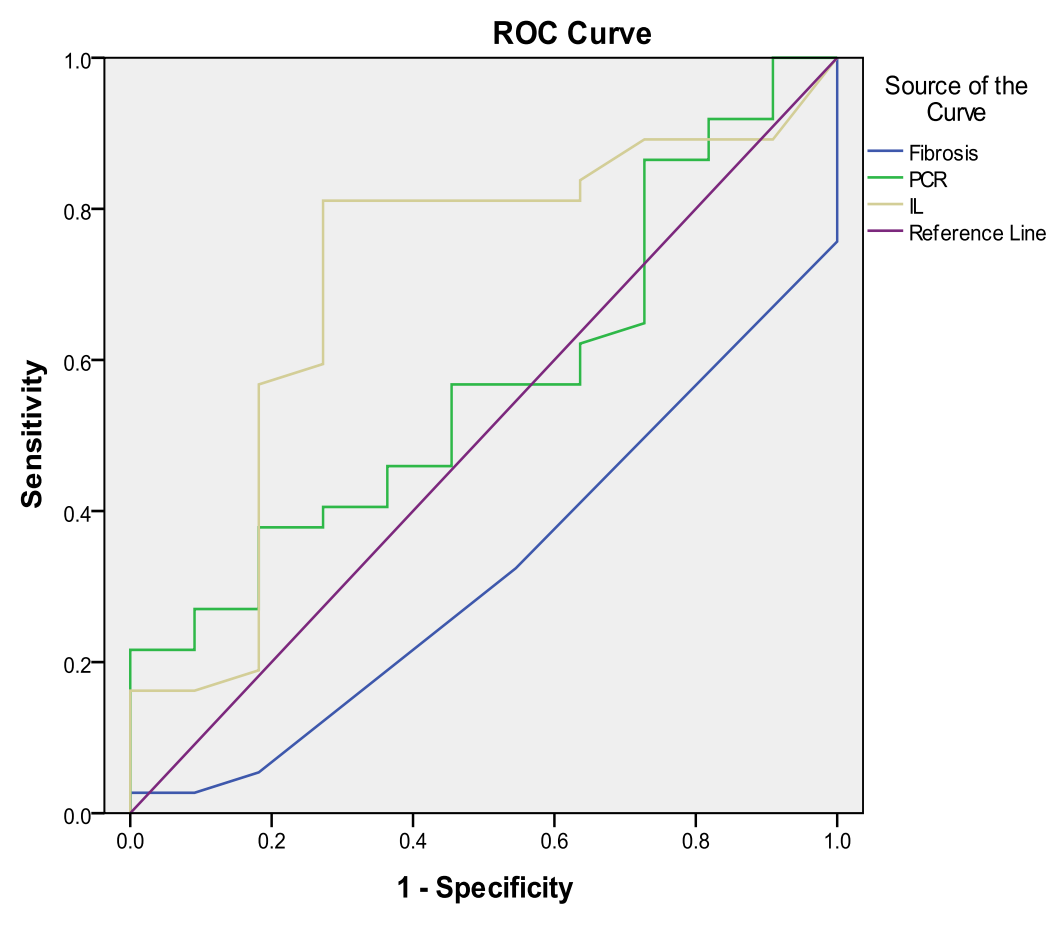

Diagonal segments are produced by ties.

Figure 1. Roc for fibrosis stage, IL-6 level and PCR

In this receiving operating characteristic curve, IL- 6 level $>2.15 \mathrm{pg} / \mathrm{ml}$ is significantly associated with EVR (p-value $=0.04)$ with $81.1 \%$ sensitivity and $72.7 \%$ specificity (95\% CI: 0.521-0.889). The fibrosis stage at a cut off $>2 / 6$ is not associated with EVR with $32.4 \%$ sensitivity and $45.5 \%$ specificity (95\% CI: $0.153-0.488)$, this was near to statistical significance $(P$ value $=0.07)$. The viral load (measured by PCR) at a cut off $>336,500$ $\mathrm{Iu} / \mathrm{ml}$ is also not associated with EVR with $56.8 \%$ sensitivity and $45.5 \%$ specificity (95\% CI: $0.389-0.754$ ) but this was statistically not significant.

Table 4. logistic regression of the fibrosis stage and IL-6

\begin{tabular}{|c|c|c|c|c|c|c|c|}
\hline \multirow{2}{*}{ Variable } & \multirow{2}{*}{ B } & \multirow{2}{*}{ Std error } & \multirow{2}{*}{ Wald } & \multirow{2}{*}{ significance } & \multirow{2}{*}{ Expected (B) } & \multicolumn{2}{|c|}{ 95\% CI of expected (B) } \\
\hline & & & & & & Lower & upper \\
\hline Fibrosis & -0.666 & 0.379 & 3.087 & 0.08 & 0.514 & 0.245 & 1.08 \\
\hline IL-6 & 0.623 & 0.492 & 4.492 & 0.03 & 1.865 & 1.048 & 3.318 \\
\hline Constant & 1.127 & 1.109 & 1.033 & 0.31 & 3.087 & & \\
\hline
\end{tabular}

\section{Discussion}

There are a series of viral, host and treatment characteristics that influence the likelihood of $\mathrm{HCV}$ treatment success and are useful when assessing the benefits and risks of therapy [23].

In this study, 48 patients did PCR after 12 week of treatment with combined PEG IFN and Ribavirin. 77\% of patients develop EVR, and 23\% of patients didn't develop EVR. This finding is comparable with the finding of [24] who found the response rate is $65 \%$ for genotype 4 . It is higher than the finding of [25]. They found that for genotype 1 , the response rate was $48 \%$, and $61 \%$ for all genotypes. Also [26] found that the response rate for genotype 1 is $56 \%$ or $44 \%$ according to whether PEG-IFN $\alpha-2 \mathrm{a}$ or PEG-IFN $\alpha$-2b is used respectively.

In this study low basal viral load is significantly associated with EVR. This finding is in agreement with previous studies $[27,28]$ who demonstrated that low pretreatment viral load is significantly associated with
SVR. We found also that basal HCV RNA $<336,500$ $\mathrm{UI} / \mathrm{ml}$ is associated with EVR, but this failed to reach the statistically significance. It is demonstrated that $\mathrm{HCV}$ RNA<400,000 IU/mL (OR 2.74; 95\% CI: 1.03-7.27) is an independent predictor of rapid virological response [29]. Another study by Berg et al.,(30) showed that Patients with a high viral load $>800,000 \mathrm{IU} / \mathrm{ml}$ are less sensitive to the treatment than patients with a low viral load $<800,000$ $\mathrm{IU} / \mathrm{ml}$.

A possible explanation of this finding is that several HCV viral proteins (E2, NS5A, and core protein) have been shown to inhibit IFN- $\alpha$ activation of signals and antiviral proteins [24].

In this study we found that mean level of $\alpha$ fetoprotein was higher in non-responders (3.2 $\pm 1.2 \mathrm{ng} / \mathrm{ml})$ than responders $(2.3 \pm 1.3 \mathrm{ng} / \mathrm{ml})$, but this difference was statistically not significant. This finding is in agreement with the finding of [31] who found that $\alpha$ fetoprotein level was significantly lower in patients who had SVR than non-responder patients.

In this study we found that there are a high percentage of non-responders who have positive anti-schistosomal 
antibody test. This difference was statistically not significant. This finding is in agreement with the finding of [32] who reported that CHC patients with schistosoma co-infection responded poorly to interferon therapy and had a higher relapse rate than HCV patients not having concomitant schistosomiasis. Previous studies showed that schistosomiasis upregulated thymus-dependent type 2 response (Th-2) while downregulating CD4+ Th-1 responses, leading to persistence of concomitant viral infections. Moreover, there is a significant decrease in core-specific CD8+ T Cell interferon gamma, IL-4, and IL-10 responses [33].

We noted in this study that there is no significant difference in AST and ALT level between responders and non-responders. The mean AST level in responders is 36.0 $\pm 28.0 \mathrm{U} / \mathrm{l}$. This finding is in agreement with the finding of [34] who demonstrated that serum AST levels $<40 \mathrm{U} / \mathrm{l}$ is correlated independently with complete response. Pockros et al. [35] demonstrated that there is no significant difference in ALT level between responders and non-responders.

In this study there is no significant difference in serum albumin between responders and non-responders. In contrast, it was reported that serum albumin $<3.9 \mathrm{~g} / \mathrm{dl}$ is significantly associated with a non-virological response [34].

We noted in this study that both responders and nonresponders had low total billirubin serum level with no statistically significant difference. Hosogaya et al., [36] reported that low total billirubin level is significantly associated with SVR.

A possible explanation of this finding is that the patients with co-infections have higher HCV-RNA titers, more advanced liver disease, more hepatic complications, and a greater mortality rate than those infected with only HCV [37]. This favors the persistence of HCV and nonresponse to interferon therapy. patients with minimal HAI reported $100 \%$ response rate, those with mild HAI reported $76 \%$ response rate and patients with moderate grade of HAI reported the lowest response rate $50 \%$. This finding is in agreement with the finding of others [38,39,40,41]. They reported that patients with advanced liver necroinflamatory activity and fibrosis have poor SVR.

This finding may be explained by that the severity of hepatic inflammation is a major factor driving progression of chronic hepatitis $\mathrm{C}$ to cirrhosis. The more advanced liver disease is more associated with poor response to IFN therapy [35].

In this study, regarding IL-6 -174 promoter polymorphism, we reported that CC genotype showed higher response rate (80\%) than GG genotype (57\%), and CG genotype (50\%). This finding is in agreement with another study [42] founded that CG and GG genotypes are significantly associated with lower rate of SVR

This finding may be explained by that we found that IL6 was expressed in high level in CC genotype and the correlation between IL-6 level and response was significant. As we discussed, IL-6 can overcome HCV core-induced inhibition of STAT 3 activation and phosphorylation, improving the response rate. $\mathrm{CHC}$ patients who achieved EVR have significantly higher IL-6 level than those who didn't. IL-6 level > $2.15 \mathrm{pg} / \mathrm{ml}$ (OR: 1.8; 95\% CI: 1.048- 3.318) is significantly associated with
EVR and can be considered as an independent predictor of EVR (p-value $=0.04$ with $81.1 \%$ sensitivity and $72.7 \%$ specificity).

The association between IL-6 level and response to treatment may be explained by that IL-6 has been shown to activate STAT3 by phosphorylation in hepatic stellate cells and promote their survival and proliferation. Activation of STAT3 is followed by induction of a wide variety of antiviral and proapoptotic genes that may contribute to the antiviral and antitumor activities of IFNd. in human livers [43].

We found in this study the mean stage of fibrosis is significantly higher in non-responders than responder patients, and fibrosis stage $\leq 2 / 6$ is associated with EVR (OR: 0.514; 95\% C.I 0.245-1.080). This association was statistically near to significance $(\mathrm{P}$ value $=0.079$, with sensitivity= $32.4 \%$ and specificity $=45.5 \%$ ).

Another researcher $[44,45]$ found that patients with established cirrhosis are more resistant to IFN- $\alpha$ therapy than those who have fibrosis, whereas patients with fibrosis are less responsive to IFN- $\alpha$ therapy than those without fibrosis.

This also agrees with the findings of other group [46] who found that the mean fibrosis was lower between responders $(1.41 \pm 0.88$ vs. $2.16 \pm 1.39 ; \mathrm{P}=.0001)$. The low fibrosis stage $(\leq 2 / 6)$ is significantly associated with EVR and can be used as independent predictor of EVR (OR, 1.36; 95\% CI, 1.01-1.84; $\mathrm{P}=.029$ ). This finding may be explained by that changes in intrahepatic inflammatory response and mediators during fibrosis progression may affect combined PEG-IFN and Ribavirin response [43].

In this study, we reported that mean insulin resistance (measured by HOMA-IR) is high in both responders (4.0 \pm 3.6) and non-responders $(3.6 \pm 3.1)$ with no statistically significant difference. This finding is in agreement with a study of Fattovich et al., [29] who reported that the mean HOMA-IR score was $(2.9 \pm 3.0)$ with no statistically significant difference between responders and nonresponders. Another study [47] showed also that there is no significant difference in HOMA-IR between responders and non-responders.

We reported in this study that the mean fasting insulin level is higher in non-responders than responders, but the difference was statistically not significant. This finding is in agreement with the finding of others [48], who found that Hyperinsulinaemia is associated with low SVR.

This finding may be explained by that HCV core protein, has been proposed to cause IR in hepatocytes by reducing the level or activity of molecules involved in insulin signaling, particularly IRS-1 (insulin receptor substrate-1) and IRS-2 [49]. This can increase insulin level and insulin resistance in CHC patients. In addition, activation of SOCS3 by the viral core protein inhibits IFN- $\alpha$-induced signaling and antiviral activity [50].

\section{Conclusion}

In this study, serum the IL-6 level is significantly higher in responder patients and can be used as an independent predictor to response to therapy. The low fibrosis stage and low viral load are significantly associated with early response to therapy. 


\section{References}

[1] Lauer G.M, Walker B.D. Hepatitis C virus infection. N Engl J Med. 2001; 345(1):41-524.

[2] Zeuzem S. Heterogeneous virologic response rates to interferonbased therapy in patients with chronic hepatitis C: who respond less well? Ann Intern Med 2004; 140: 370-81.

[3] Khattab M, Eslam M, Sharwae MA, Shatat M, Ali A, Hamdy L. Insulin resistance predicts rapid virologic response to peginterferon/ribavirin combination therapy in hepatitis C genotype 4 patients. Am J Gastroenterol. 2010 Sep;105(9):1970-7.

[4] Egypt Demographic and Health Survey 2011. Cairo, Egypt: Ministry of Health.

[5] Neumann AU, Lam NP, Dahari H, Gretch DR, Wiley TE, Layden TJ, Perelson AS: Hepatitis C viral dynamics in vivo and the antiviral efficacy of interferon-alpha therapy. Science 1998, 282:103-107.

[6] McHutchison JG, Gordon SC, Schiff ER, Shiffman ML, Lee WM, Rustgi VK, Goodman ZD: Interferon alfa-2b alone or in combination with ribavirin as initial treatment for chronic hepatitis C. Hepatitis Interventional Therapy Group. N Engl J Med 1998, 339:1485-1492.

[7] Poynard T, Marcellin P, Lee SS, Niederau C, Minuk GS, Ideo G, Bain V: Randomised trial of interferon alpha2b plus ribavirin for 48 weeks or for 24 weeks versus interferon alpha2b plus placebo for 48 weeks for treatment of chronic infection with hepatitis C virus. International Hepatitis Interventional Therapy Group (IHIT). Lancet 1998, 352:1426-1432.

[8] Reichard O, Norkrans G, Fryden A, Brachonier JH, Sonnerborg A, Weiland O: Randomized double blind, placebo controlled trial of interferon alpha $2 \mathrm{~b}$ with and without ribavirin for chronic hepatitis C. Lancet 1998, 351:83-7.

[9] Di Bisceglie et al., 2007Di Bisceglie AM, Ghalib RH, Hamzeh FM, Rustgi VK. 2007;Early virologic response after peginterferon alpha-2a plus ribavirin or peginterferon alpha-2b plus ribavirin treatment in patients with chronic hepatitis C. J Viral Hepat, 14:721-9.

[10] Sim KH, Wojccik JP, Margulies M, Wade J, Heathcote J: Human leukocyte antigen class II alleles may affect response of chronic hepatitis C to interferon therapy. J Viral Hepat 1998, 5:249-253.

[11] Davis GL, Lau JY: Factorespredictive of beneficial response to therapy of hepatitis C. Hepatology 1997, 26(3 Suppl 1):122S-127S.

[12] Camps J, Crisostomo S, Garcia-Granero M, Riezu-Boj JI, Civeira MP, Prieto J: Prediction of the response of chronic hepatitis C to interferon alfa: a statistical analysis of pre-treatment variable. Gut 1993, 34:1714-1717.

[13] Hayashi J, Kishihara Y, Ueno K, Yamaji K, Kawakami Y, Furusyo N, Sawayama Y: Age-related response to interferon alfa treatment in women vs men with chronic hepatitis C virus infection. Arch Intern Med 1998, 158:177-181.

[14] Manns MP, McHutchison JG, Gordon SC, Rustgi VK, Shiffman M, Reindollar R, Goodman ZD, Koury K, Ling M, Albrecht KJ: Peginterferon alfa-2b plus ribavirin compared with interferon alfa$2 \mathrm{~b}$ plus ribavirin for initial treatment of chronic hepatitis C: a randomized trial. Lancet 2001, 358:958-965.

[15] Poynard T, Marcellin P, Lee S, Niederau C, Minuk GS, Ideo G, Bain V: Randomised trial of interferon alpha2b plus ribavirin for 48 weeks or for 24 weeks versus interferon alpha2b plus placebo for 48 weeks for treatment of chronic infection with hepatitis C virus. International Hepatitis Interventional Therapy Group (IHIT). Lancet 1998, 352:1426-1432.

[16] Wazir MS, Majid AS, Solangi GA, Zuberi BF: Role of interferon and interferon plus ribavirin in the management of chronic hepatitis C. J CollPhysSurgeo, Pak 2002, 12:609-612.

[17] Shafi MS, Ahmad SI, Rehana M, et al.: Daily interferon versus interferon TIW in combination with ribavirin for treatment of chronic hepatitis C. JRMC 1999, 31:20-2. hepatitis C. Aliment PharmacolTher 2010; 31: 1251-67.

[18] Zeuzem S. Heterogeneous virologic response rates to interferonbased therapy in patients with chronic hepatitis C: who respond less well? Ann Intern Med 2004;140: 370-381.

[19] Bressler BL, Guindi M, Tomlinson G, Heathcote J. High body mass index is an independent risk factor for nonresponse to antiviral treatment in chronic hepatitis C. Hepatology 2003; 38: 639-44.
[20] Durante-Mangoni E, Zampino R, Portella G, et al. Correlates and prognostic value of the first-phase hepatitis $C$ virus RNA kinetics during treatment. ClinInfect Dis 2009; 10: 43-9.

[21] Yu ML, Dai CY, Huang JF, et al. Rapid virologic response and treatment duration for chronic hepatitis C genotype 1 patients: a randomized trial. Hepatology 2008; 47: 1884-93.

[22] Poordad FF. Review article: the role of rapid virological response in determining treatment duration for chronic.

[23] boback D.The next era of HCV antiviral therapy. Current Infections rep.2010:12(2):79-80.1-Leiveven J: Pegasys/RBV Improves Fibrosis in Responders, relapsers \& Nonresponders with Advanced Fibrosis. In 55th Annual Meeting of the American Association for the Study of Liver Disease: 2004 October 29November 2. Boston, MA, USA;

[24] Pawlotsky JM. Mechanisms of antiviral treatment efficacy and failure in chronic hepatitis C. Antiviral Res, 2003; 59: 1-11.

[25] Manns M, McHutchison J and Gordon S. Peginterferon alfa-2b plus ribavirin compared with interferon alfa-2b plus ribavirin for initial treatment of chronic hepatitis C: a randomised trial. Lancet, 2001; 358:958-65.

[26] Fried MW, Shiffman ML, Reddy KR, Smith C, Marinos G and Gonçales FL Jr. Peginterferon alfa-2a plus ribavirin for chronic hepatitis C virus infection. N Engl J Med, 2002; 347(13):975-82.

[27] Zeuzem S, Buti M and Ferenci P. Efficacy of 24 weeks treatment with peginterferon alfa-2b plus ribavirin in patients with chronic hepatitis $C$ infected with genotype 1 and low pretreatment viremia. J Hepatol, 2006; 44:97-103.

[28] Moucari R, Asselah T, Cazals-Hatem D, Voitot H, Boye N, Ripault MP, Paradis V, Vidaud M, Valla D, Marcellin P. Insulin resistance in chronic hepatitis $\mathrm{C}$ : association with genotypes 1 and 4, serum HCV RNA level, and liver fibrosis. Gastroenterology 2008, 134:416-423.

[29] Fattovich, L. Covolo, S. Bibert, G. Askarieh, M. Lagging, S. Santantonio, and G. Raimondo. IL28B Polymorphisms, IP-10 and Viral Load Predict Virological Response to Therapy in Chronic Hepatitis C. Alimentary Pharmacology \& Therapeutics 2011, 33(10):1062-1072.

[30] 30-Berg $\mathrm{T}$, Weich $\mathrm{V}$ and Teuber G. Individualized treatment strategy according to early viral kinetics in hepatitis $C$ virus type 1-infected patients. Hepatology 2009, 50:369-77.

[31] Abdoul H, Mallet V, Pol S, Fontanet A. Serum Alpha-Fetoprotein Predicts Treatment Outcome in Chronic Hepatitis C Patients Regardless of HCV Genotype. PLoS ONE 2008; 3(6): e2391.

[32] Kamal S M, Graham C S, He Q, Bianchi L, Tawil A A, Rasenack J W. Kinetics of intrahepatic hepatitis C virus (HCV)-specific CD4+ $\mathrm{T}$ cell responses in HCV and Schistosomamansonico infection: relation to pro-gression of liver fibrosis. J Infect Dis, 2004; 189:1140-1150.

[33] Kamal S M, Madwar M A, Peters T, Fawzy R, Rasenack J. Interferon therapy in patients with chronic hepatitis $\mathrm{C}$ and schistosomiasis. J Hepatol 2000, 32:172-174.

[34] Pérez Roldán F, De Diego A, Casado M, Matilla A, Bañares R, García-Durán F, Salcedo M, Cos E, Clemente G. Treatment with interferon alfa-2b in patients with chronic hepatitis caused by hepatitis $\mathrm{C}$ virus: predictive factors for the response, relapse and early development to cirrhosis after treatment. Rev EspEnferm Dig 1996, 88(9):609-15.

[35] 35-Pockros P J, Hamzeh F M, Martin P, Lentz E, Zhou X, Govindarajan S. Histologic Outcomes in Hepatitis C Infected Patients with Varying Degrees of Virologic Response to Interferon-Based Treatments. Hepatology 2010; 52(4):1193-1200.

[36] Hosogaya S, Ozaki Y, Enomoto N, Akahane Y. ;Analysis of prognostic factors in therapeutic responses to interferon in patients with chronic hepatitis C. Transl Res, 2006 148(2):79-86.

[37] Madwar M, Bianchi L, Tawil A E, Fawzy R, Peters T. Clinical, virological and histopathological features: long-term follow-up in patients with chronic hepatitis C co-infected with S. mansoni. Liver 2000, 20:281-289.

[38] Balart L, Lee S S, Everson GT, Reindollar R W, Shiffman M L, Minuk G Y. Histological benefits of virological response to peginterferon alfa-2a monotherapy in patients with hepatitis $\mathrm{C}$ and advanced fibrosis or compensated cirrhosis. Aliment Pharmacol Ther 2008, 27:542-551.

[39] Everson G T, Jensen D M, Craig J R, van Leeuwen D J, Bain V G, Ehrinpreis M N. Efficacy of interferon treatment for patients with chronic hepatitis C: comparison of response in cirrhotics, fibrotics, or nonfibrotics. HEPATOLOGY 1999, 30:271-276. 
[40] Shiffman M L, Hofmann C M, Thompson E B, Gonzalez F, Contos M J, Koshy A and Luketic A V. Relationship Between Biochemical, Virological, and Histological Response During Interferon Treatment of Chronic Hepatitis C. Hepatology, 1997; 26:780-785.

[41] Yano M, Kumada H, Kage M, Ikeda K, Shimamatsu K, Inoue O, Hashimoto E, Lefkowitch J H, Ludwig J, Okuda K. The long-term pathological evolution of chronic hepatitis C. HEPATOLOGY 1996;23: 1334-1340.

[42] Yee LJ, Im K, Borg B, Yang H, Liang TJ. Interleukin-6 haplotypes and the response to therapy of chronic hepatitis $C$ virus infection. Genes Immun 2009; 10:365-372.

[43] Gao B. Cytokines, STATs and liver disease. Cell MolImmunol. 2005;2(2):92-100.

[44] Banner BF, Barton AL, Cable EE, Smith L and Bonkovsky HL.A detailed analysis of the Knodell score and other histologic parameters as predictors of response to interferon therapy in chronic hepatitis C. Mod Pathol, 1995; 8: 232-238.

[45] Poynard T, Marcellin P, Lee SS, Niederau C, Minuk GS, Ideo G, Bain V: Randomised trial of interferon alpha2b plus ribavirin for 48 weeks or for 24 weeks versus interferon alpha2b plus placebo for 48 weeks for treatment of chronic infection with hepatitis C virus. International Hepatitis Interventional Therapy Group (IHIT) Lancet 1998, 352:1426-1432.

[46] Romero-Gómez M, Salmerón J, Diago M, Grande L and Vázquez $\mathrm{L}$. Insulin resistance impairs sustained response rate to peginterferon plus ribavirin in chronic hepatitis C patients. Gastroenterology 2005,128: 636-641.

[47] Petta S, Cammà C and Di Marco V. Time course of insulin resistance during antiviral therapy in non-diabetic, non-cirrhotic patients with genotype $1 \mathrm{HCV}$ infection. AntivirTher 2009, 14: 631-9.

[48] Bortoletto G, Scribano L and Realdon S. Hyperinsulinaemia reduces the virological response to PEG-interferon therapy in patients with chronic hepatitis $\mathrm{C}$ and insulin resistance. J Viral Hepat 2010; 17: 475-80.

[49] Alaei $M$ and Negro F. Hepatitis $C$ virus and glucose and lipid metabolism. Diabetes Metab 2008, 34: 692-700.

[50] Persico M, Capasso M, Persico E, Svelto M, Russo R, Tiribelli C and Iolascon A; Suppressor of cytokine signaling 3 (SOCS3) expression and hepatitis $\mathrm{C}$ virus-related chronic hepatitis: Insulin resistance and response to antiviral therapy. Hepatology 2007, 46: 1009-1015. 